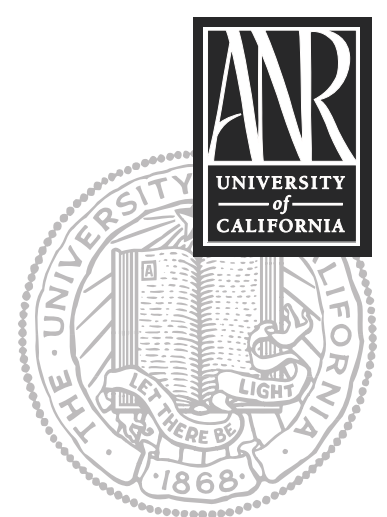

UNIVERSITY OF CALIFORNIA

Division of Agriculture and Natural Resources http://anrcatalog.ucdavis.edu

\title{
Home Landscaping for Fire
}

GLENN NADER, UCCE Livestock and Natural Resources Advisor, Sutter-Yuba-Butte Counties; GARY NAKAMURA, Area Forestry Specialist; Codirector of Center for Forestry, UC Berkeley; MIKE DE LASAUX, UCCE County Director and Natural Resources Advisor, Plumas-Sierra Counties; STEVE QUARLES, UCCE Wood Durability Advisor, Contra Costa County; and YANA VALACHOVIC, UCCE Forest Advisor, Humboldt-Del Norte Counties

More than 1,445 structures are destroyed by wildfire each year just within the jurisdiction of California's Department of Forestry and Fire Protection (CAL FIRE).

However, many homes are also saved as a result of the owners' careful pruning and landscaping techniques that minimize ignition of vegetation and spread of fire to their homes (CAL FIRE 2005).

Incorporating fire safe concepts into the residential landscape is one of the most important ways you can help your home survive a wildfire. When conditions are dry and windy, the grasses, brush, trees, or other vegetation surrounding your home become a dangerous fuel source. Creating an area of defensible space (or area of reduced fuel) between your home and flammable vegetation reduces the risk of home ignition. When the vegetation is removed, pruned, or otherwise modified, the chance that its ignition will pose a serious threat to your home during a wildfire diminishes. Your home may be the most valuable investment you ever make. If you live in a highrisk fire hazard area, protect against the chance of losing that investment by implementing the recommendations in this publication.

Creating an area of defensible space does not mean you need a ring of bare dirt around your home. Through proper planning, you can have both a beautiful landscape and a fire safe home. The general concept is that trees should be kept furthest from your house, shrubs can be closer, and bedding plants and lawns may be nearest the house.

\section{VEGETATION ARRANGEMENT}

From a wildfire fuel standpoint, vegetation is often described in terms of its vertical and horizontal arrangement. Sometimes the arrangement is described in terms of vertical or horizontal fuel continuity. Vertical fuel continuity is also referred to as 'ladder' fuels (fig. 1).

Fire climbs neighboring trees like a ladder. To reduce the chance of fire climbing a tree, remove lower tree limbs 6 to 15 feet from the ground (or the lower third of branches on smaller trees).

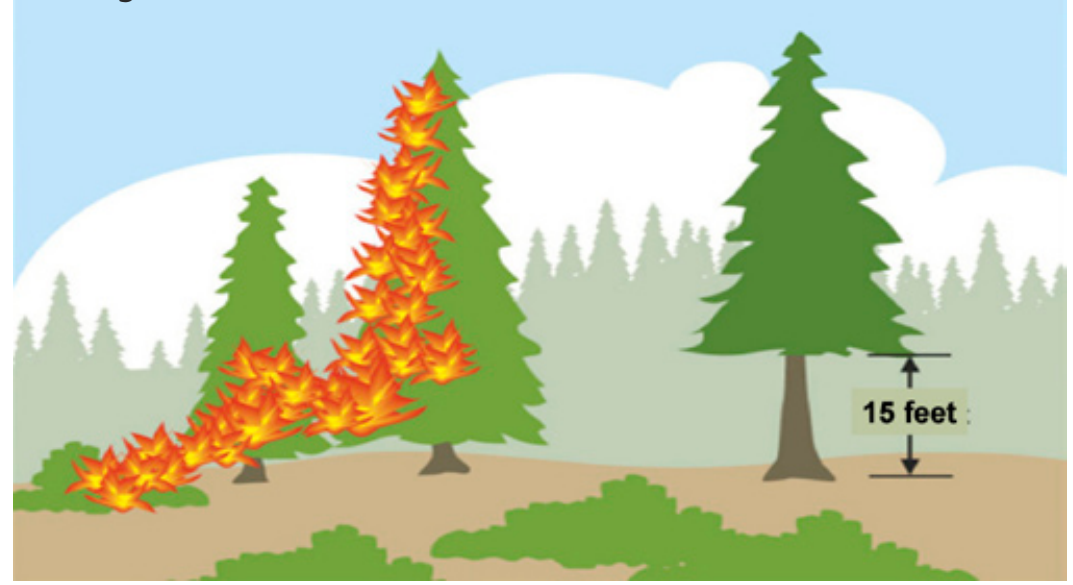

Figure 1. Eliminate ladder fuels to minimize the movement of ground fire into the crown of a tree. Source: Riverside County Fire. 


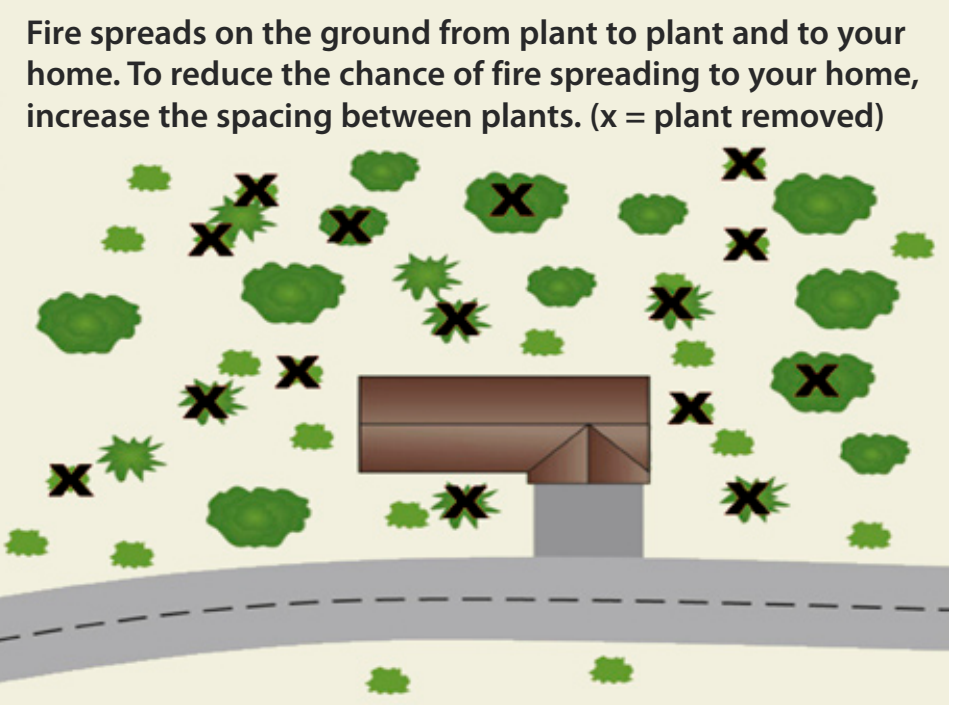

Figure 2. Horizontal arrangement of vegetation. Source: Riverside County Fire.

Most wildfires begin as surface fires. They will not reach the crown of a tree if the vertical fuel continuity has been eliminated. Once the fire reaches the crown of a tree, the heat intensity (the energy released and flame length when vegetation burns) is increased; this can then increase the combustibility of the surrounding vegetation. Therefore, it is important to prune taller trees by removing branches that are close to the ground.

Horizontal fuel continuity allows the fire to spread across the landscape. Breaking up the horizontal fuel continuity through wider spacing of the vegetation can greatly reduce the fire intensity (fig. 2). The wider the spacing between plants, the greater the wind velocity must be to spread the fire. The actual between-plant spacing depends on one's aversion to the risk of fire spreading to one's home, and the associated chance of losing it. Ultimately, choices regarding the selection, placement, and maintenance of near-home vegetation, plus choices regarding the material selection and maintenance of your home, will affect whether or not your home survives a wildfire.

\section{TWO IMPORTANT ZONES AROUND YOUR HOME}

A fire safe landscape consists of two zones: the home defense zone and the reduced fuel zone (fig. 3). The home defense zone is within 30 feet of the house. The reduced fuel zone lies beyond the home defense zone and extends out at least 100 feet from

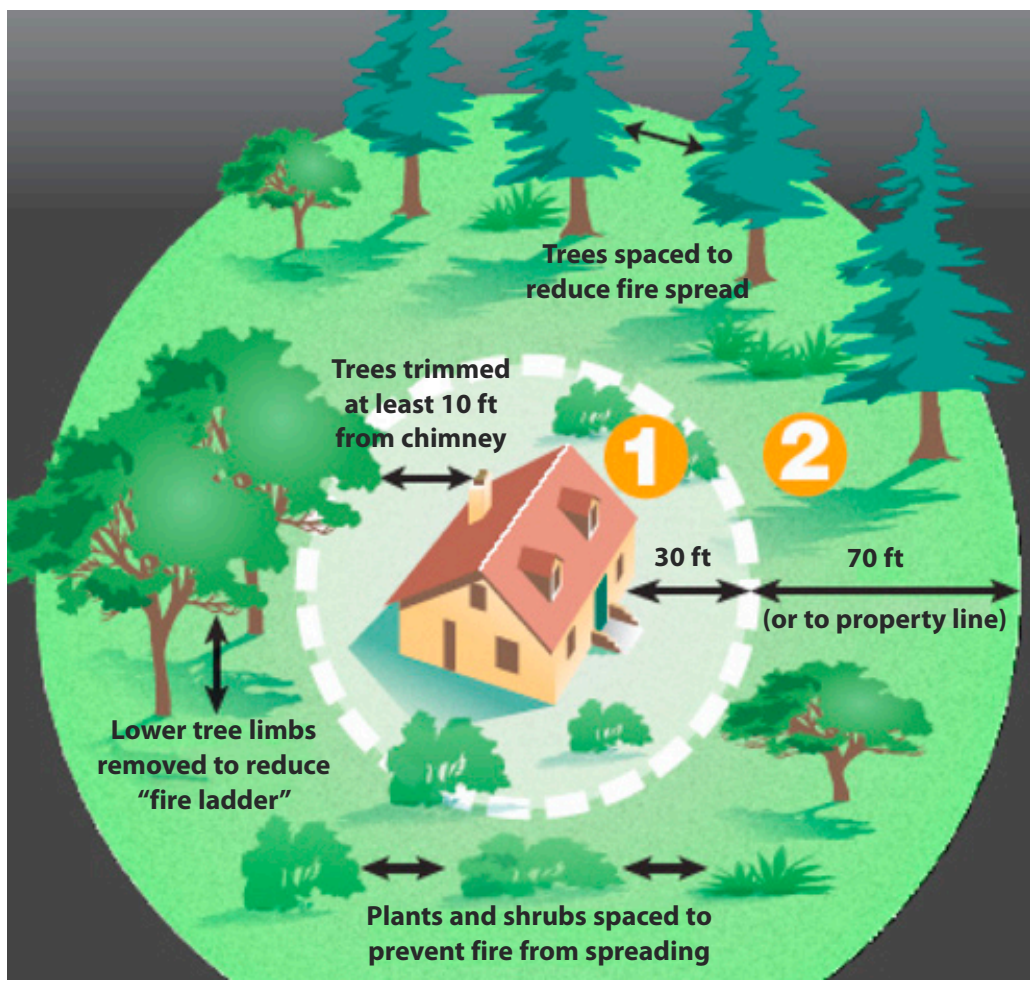

Figure 3. Keep branches trimmed at least 10 feet from your roof and eliminate combustible plants or material under the eaves and next to the house siding and vents. Source: CAL FIRE. the house or to your property line. (See the metric conversion table at the end of this publication.) Greater defense zone widths are necessary when your home is on a steep slope or in a windswept exposure. Specific recommendations for each zone are described below and pertain to the State Responsibility Area (SRA) protected by CAL FIRE. Local Responsibility Areas that are protected by fire departments may have different requirements.

\section{HOME DEFENSE ZONE}

The 2005 revision of California Public Resources Code \& 4291 requires the removal and clearance of all flammable vegetation and other combustible growth within 30 feet of the house, with certain exceptions. Single specimens of trees, shrubs, or other vegetation may be retained provided that they are well spaced and well pruned. In other words, the landscape condition should not support the spread of fire to other vegetation or to a building or structure. 
The objectives of the home defense zone include the following:

- Maintain high moisture content in the vegetation.

- Decrease plant fuel density by increasing space between the branches.

- Shorten plant height.

- Create and maintain proper spacing between plants and the home.

- Remove combustible materials (such as firewood, twigs, needles and leaves, dry or cured grasses, shrubs, woodpiles, building materials, cardboard boxes, and solvents) within 30 feet of the home, garage, outbuildings, and propane or other fuel tanks.

Your home can be exposed to fire in three different ways:

\section{Embers}

These are glowing or burning pieces of vegetation or construction debris that are lofted during the wildfire. Embers can move up to a mile ahead of a fire storm. These small embers or sparks may fall on the vegetation near your home; on dry leaves, needles, or twigs on your roof; on the roof and then subsequently concentrate within 5 feet of the house; or under your deck with subsequent ignition of vegetation or debris that could then ignite and burn down your house. If ignited from embers that come from outlying areas, a continuous sequence of vegetation can carry flames from your landscaping to your house. The concentration of embers that land on the roof and roll off of it makes the removal of all flammable material within 5 feet of the house critical.

\section{Radiant heat}

This is the heat given off by burning materials that is transferred through the air to other materials or objects. Radiant heat from a fire near your house can heat the surface of combustible building materials to a point where combustion occurs.

\section{Flame impingement}

This refers to the transfer of heat by direct flame exposure. Direct contact with fire flames will heat the combustible building materials of your home. Depending on the exposure (i.e., time and intensity) of the flame, materials can ignite or break. For example, in a high-intensity fire, your siding material could ignite or the glass in your windows could break.

\section{Fire Resistant Plants}

Some landscape plants are described and marketed as fire resistant. It is important to remember that, given certain conditions, all plants can burn regardless of how they are classified. In general, select plants that are low growing, open structured, and less resinous. However, how your plants are maintained and where they are placed is as important as the species of plants that you choose. Cultural practices and landscape management (e.g., pruning, irrigation, and cleanup) have a greater impact on whether or not a plant ignites than does the species. When choosing plants for a fire safe landscape, select those with the following characteristics (Barkley 2005):

- High moisture content in leaves (as these ignite and burn more slowly). Deciduous trees are generally more fire resistant than evergreens, because they have higher moisture content when in leaf.

- Little or no seasonal accumulation of dead vegetation.

- Open branching habits (as they provide less fuel for fires).

- Fewer total branches and leaves (again, less fuel for fires). 
- Slow growing, so less pruning is required (to keep open structure as noted above).

- Nonresinous material on the plant (i.e., stems, leaves, or needles that are not resinous, oily, or waxy). Junipers, pines, spruces, and firs are resinous and highly flammable.

\section{How To Plant and Maintain Vegetation}

Healthy lawn, ground cover, and perennials form a greenbelt in the home defense zone. Plants that are green and lush give better protection. If regularly watered and maintained to eliminate the accumulation of dry plant litter, these plants will be far less likely to carry fire to your home. While all plants will eventually burn, healthy ones with a high moisture content will be more difficult to ignite. Drip irrigation systems are effective and conserve water because they target where the water goes and control the quantity. Use sprinklers for lawns and ensure that your lawn is getting the right amount of water to keep it green, healthy, and thereby fire resistant. The home defense zone can contain the occasional individual shrub or tree that is located at least 10 feet from the house. By grouping plants of similar height and with similar water requirements, you can create a landscape mosaic that uses water more efficiently and is more likely to slow the spread of fire.

\section{Use Noncombustible Materials}

Use masonry, gravel, or stone walls to separate plant groups, thus adding to the variety and improving the fire resistance of your landscape. Another way to break up fuel continuity is to use decorative rock, gravel and stepping stone pathways, cement driveways and walkways, and retaining walls as your landscape's "hardscape" that is less flammable. Replace bare, weedy, or unsightly patches near your home with ground cover, rock gardens, vegetable gardens, and fire resistant mulches.

\section{Mulch Conserves Moisture But Also Burns}

Carefully choose the location of plants or garden beds that will need mulch. Mulches are valuable because they conserve moisture, reduce weed growth, and also cover up weed cloth. However, be careful not to use too much bark mulch in garden beds near your home or outbuildings. In general, fine (less than $1 / 4$ inch particles) or stringy mulches ignite and burn more rapidly than larger chunks. When exposed to fire, thick mulch layers (greater than 2 inches deep) tend to smolder and are difficult to extinguish. Do not use wood or bark mulches within 3 to 5 feet of the house. Instead consider colored rock or other less flammable material.

\section{Where To Plant}

Avoid putting plants in the following locations to minimize the movement of fire from vegetation to the home:

- adjacent to the siding

- under vents or eaves

- tree limbs over the roof

- under or near the deck

\section{REDUCED FUEL ZONE}

The reduced fuel zone is an area adjacent to the home defense zone. It extends out at least an additional 70 feet away from the house (for a total of 100 feet), where the ground slope around the home is less than 10 percent. In this zone the trees and brush should be thinned out. To determine the additional distance required for slopes of more than 10 percent, multiply the number of degrees over 10 percent for 
the uphill and sides by three and add it to 100. On the downhill side, multiply the number of degrees over 10 percent by five and add to 100 . The key words here are "at least." Your local fire department or insurance company may ask that a larger area be treated. Contact them for requirements in your area.

\section{Trees}

For slopes that are less than 20 percent, trim or space existing trees so that there is 10 feet of space between the tips of their limbs. Increase the space to 20 feet for slopes that are 20 to 40 percent. For steep slopes over 40 percent, 30 feet of spacing is needed (Simmerman and Fischer 1990). When planting trees, allow for future growth by spacing them 20 to 30 feet apart. If trees are over 18 feet tall, prune limbs up to a height of 6 to 15 feet to reduce the possibility of surface fires spreading into the tree crowns. In order to avoid stress to the tree, no more than one-third of a tree's live limbs should be removed by pruning. Eliminate other ladder fuels by removing all shrubs from around the base of trees.

\section{Shrubs}

Due to flammability, shrubs should not be used as a visual screen for propane tanks, firewood piles, or other flammable materials. To reduce the fire-spreading potential of shrubs, only plant varieties that are widely separated, low growing, deciduous, and nonresinous. These can be planted individually or in small clumps. The spacing between plants depends on the slope of property. The rule of thumb for spacing (Smith 1998) is:

\section{Slopes \\ 0 to 20 percent \\ 20 to 40 percent greater than 40 percent}

Spacing

2 times the height of the shrub

4 times the height of the shrub

6 times the height of the shrub

Yard waste from landscape maintenance can create another fire hazard. This debris should be promptly and legally disposed of to provide a clean, neat landscape. Some Fire Safe Councils provide free chipping programs to assist in the reduction of fuel around the home.

\section{Annual Maintenance}

Maintenance is critical to fire safety. Over time, plants grow vertically and horizontally; mulches dry out, and leaves and needles accumulate within and around vegetation. All of these contribute to the fuels on which a fire can feed. Even in fire safe landscapes, the accumulation of leaf litter and other debris can give fire a chance to start under porches and decks and on roofs. Regular cleanup is necessary to maintain the fire resistance of your landscape. This is especially true during the fire season. In general:

- Keep plants green during the dry season and use supplemental irrigation if necessary.

- Move and stack firewood at least 30 feet from your home during the fire season. The wood can be moved closer to the home during the winter months when you would be using it.

- Mow grasses during the green growing season to reduce the potential for fastmoving surface fires. Sparks that can be generated when mowing in dry grass during the fire season can ignite a fire.

- Clean all needles and leaves from the roof, eaves, and rain gutters to protect the roof. Clearing against the foundation provides protection against ignition of the siding. 
- Clear all vegetation and other flammable materials from beneath your deck.

- Keep trees trimmed at least 10 feet from your chimney and trim all dead limbs hanging over your house or garage.

- Annually check and prune trees and shrubs to maintain the recommended distance between plants.

Lack of attention to these recommendations can result in plants accumulating dead twigs, leaves, and branches, whether or not they are characterized as "fire resistant." Lack of maintenance can easily result in vegetation that is very flammable.

\section{Privacy}

Many landowners move to the country in order to have either more space or screened space between them and their neighbors. Creating a fire safe landscape does not have to reduce your privacy. If possible, maintain your visual screen outside the reduced fuel zone or at least 100 feet from the home. Within this zone, arrange vegetation in small, well-spaced groups that can still provide a visual screen of your neighbor's house, while breaking up the horizontal fuel continuity and thereby protecting your home from fire.

\section{BEYOND THE REDUCED FUEL ZONE}

When your parcel is greater than an acre or two, you should also consider treating the vegetation all the way to the property line. Many people purchase their property because of the surrounding aesthetics. Protecting your home is very important, but most people would be disappointed to save their home and yet have the surrounding environment burned in a fire.

The same treatment guidelines apply when reducing fuel beyond the reduced fuel zone. Create horizontal and vertical space throughout the vegetation, whether it is shrubland, woodland, or forest.

\section{CONCLUSION}

How much or how little homeowners do with their landscaping in fire-prone areas is a measure of their risk aversion to losing their home. The best way to protect your home against fire is to keep the surrounding area clear of fine fuels (dry leaves, grass, or other dry vegetation touching your house), design your landscape to be fire safe, and use appropriate building materials and routine maintenance.

\section{REFERENCES}

Barkley, Y., C. Schnepf, and J. Cohen. 2005. Protecting and landscaping homes in the wildland/urban interface. Idaho Forest, Wildlife, and Range Experiment Station Bulletin No. 67. Moscow: University of Idaho Extension. USDA Forest Service Rocky Mountain Research Station Web site, http://www.fs.fed.us/rm/pubs_other/rmrs_2004_barkeley_y001.pdf.

CAL FIRE (California Department of Forestry and Fire Protection). 2005. Make your house fire safe. CAL FIRE Web site, http://www.fire.ca.gov/about_content/downloads/Defens_space_flyer4_11final.pdf.

Simmerman, D. G., and W. C. Fischer. 1990. Wildland home fire risk meter. USDA Forest Service INT-PMS 703. Missoula Fire Sciences Lab: Rocky Mountains Research Station. 
Smith, E. 1998. Living with fire: A guide for the homeowner. Special Publication SP-98-04. Reno: University of Nevada Cooperative Extension.

Smith, E., and G. Adams. 1991. Incline Village/Crystal Bay defensible space handbook. Reno: University of Nevada.

State Board of Forestry and Fire Protection. 2006. General guidelines for creating defensible space. State Board of Forestry and Fire Protection Web site, http://www.bof.fire.ca.gov/pdfs/4291finalguidelines2_23_06.pdf.

Tennessee Department of Agriculture. N.d. Firewise landscaping. Tennessee Department of Agriculture Division of Forestry Web site, http://www.state.tn.us/agriculture/forestry/lit/firewise4.pdf\#search='Tennessee $\% 2 \mathrm{C} \% 20$ fire\%20landscaping.

\section{METRIC CONVERSIONS}

\begin{tabular}{|l|c|c|c|}
\hline English & $\begin{array}{c}\text { Conversion } \\
\text { factor for } \\
\text { English to Metric }\end{array}$ & $\begin{array}{c}\text { Conversion } \\
\text { factor for } \\
\text { Metric to English }\end{array}$ & \multicolumn{1}{c|}{ Metric } \\
\hline inch (in) & 2.54 & 0.394 & centimeter (cm) \\
\hline foot (ft) & 0.3048 & 3.28 & meter (m) \\
\hline yard (yd) & 0.914 & 1.09 & meter (m) \\
\hline mile (mi) & 1.61 & 0.62 & kilometer \\
\hline acre (ac) & 0.4047 & 2.47 & hectare (ha) \\
\hline
\end{tabular}

\section{FOR FURTHER INFORMATION}

To order or obtain printed ANR publications and other products, visit the ANR Communication Services online catalog at http://anrcatalog.ucdavis.edu. You can also place orders by mail, phone, or FAX, or request a printed catalog of our products from

University of California

Agriculture and Natural Resources

Communication Services

6701 San Pablo Avenue, 2nd Floor

Oakland, California 94608-1239

Telephone: (800) 994-8849 or (510) 642-2431

FAX: (510) 643-5470

E-mail inquiries: danrcs@ucdavis.edu

An electronic version of this publication is available on the ANR Communication Services Web

site at http://anrcatalog.ucdavis.edu.

This publication has been anonymously peer reviewed for technical accuracy by University of California scientists and other qualified professionals. This review process was managed by the ANR Associate Editor for Natural Resources.

Publication 8228

ISBN-13: 978-1-60107-446-1

(C) 2007 The Regents of the University of California

Division of Agriculture and Natural Resources

All rights reserved.

No part of this publication may be reproduced, stored in a retrieval system, or transmitted, in any form or by any means, electronic, mechanical, photocopying, recording, or otherwise, without the written permission of the publisher and the authors.

The University of California prohibits discrimination or harassment of any person on the basis of race, color, national origin, religion, sex, gender identity, pregnancy (including childbirth, and 
medical conditions related to pregnancy or childbirth), physical or mental disability, medical condition (cancer-related or genetic characteristics), ancestry, marital status, age, sexual orientation, citizenship, or status as a covered veteran (covered veterans are special disabled veterans, recently separated veterans, Vietnam era veterans, or any other veterans who served on active duty during a war or in a campaign or expedition for which a campaign badge has been authorized) in any of its programs or activities. University policy is intended to be consistent with the provisions of applicable State and Federal laws.

Inquiries regarding the University's nondiscrimination policies may be directed to the Affirmative Action/Staff Personnel Services Director, University of California, Agriculture and Natural Resources, 1111 Franklin Street, 6 ${ }^{\text {th }}$ Floor, Oakland, CA 94607-5201, (510) 987-0096. For information about ordering this publication, telephone 1-800-994-8849.

pr-7/07-LR/CM 